\title{
Degradacja budynków zabytkowych wskutek nadmiernego zawilgocenia - wybrane problemy
}

\author{
Jerzy Hola \\ Zakład Budownictwa Ogólnego, Wydział Budownictwa Lądowego i Wodnego, \\ Politechnika Wrocławska, e-mail: jerzy.hola@pwr.edu.pl
}

Streszczenie: W artykule przedstawiono wybrane, ale zdaniem autora, istotne problemy dotyczące postępującej degradacji budynków zabytkowych wskutek nadmiernego zawilgocenia. Naświetlono najważniejsze przyczyny i skutki nadmiernego zawilgocenia i zasolenia. Mówiąc o skutkach wskazano między innymi na obniżenie bezpieczeństwa konstrukcji, zmniejszenie izolacyjności cieplnej przegród zewnętrznych oraz na pogorszenie warunków eksploatacyjnych w pomieszczeniach. Omówiono uwarunkowania badania wilgotności metodami nieniszczącymi wraz ze wskazaniem użytecznych metod w budynkach zabytkowych, zasygnalizowano możliwości wykorzystania do wiarygodnej oceny wilgotności sztucznych sieci neuronowych. Sygnalnie sprecyzowano w ujęciu chronologicznym działania, które należy podejmować w celu zapobieżenia postępującej degradacji budynków zabytkowych powodowanej nadmiernym zawilgoceniem i zasoleniem.

Słowa kluczowe: budynki zabytkowe, degradacja, nadmierne zawilgocenie, nadmierne zasolenie, metody badania wilgotności, sztuczne sieci neuronowe.

\section{Wprowadzenie}

Woda, we wszystkich jej postaciach, oddziałując na materiały o strukturze kapilarno-porowatej może przy sprzyjających warunkach środowiskowych uaktywniać proces ich destrukcji. Może się do tego przyczynić mróz, ale również zawartość szkodliwych domieszek w postaci rozpuszczalnych w wodzie soli. Jest udowodnione, że im większe jest stężenie soli w wodzie, tym intensywniejszy jest przebieg tego procesu. Wiadomo także, że strukturą kapilarno-porowatą cechuje się wiele materiałów i wykonanych z nich wyrobów budowlanych. Są to m.in. cegła ceramiczna i zaprawy budowlane, charakteryzujące się znaczną porowatością, stosowane w przeszłości powszechnie do budowy nie tylko fundamentów i ścian, ale także sklepień budynków.

W wielu krajach europejskich znaczna część budynków, których zachowanie w należytym stanie technicznym leży w interesie społecznym ze względu na ich wartość historyczną, posiada nadmiernie zawilgocone i zasolone ceglane mury podziemia - nierzadko grube lub bardzo grube, przyziemia i nadziemia oraz ceglane sklepienia nad piwnicami. Mury, o których mowa, mogą być jednorodne materiałowo, mogą też mieć rdzeń wykonany z gruzu ceglanego i zaprawy wapiennej i wtedy charakteryzują się bardzo wysoką tzw. porowatością aktywną [1]. W przypadku ścian wykonanych z elementów murowych kamiennych, charakteryzujących się bardzo niską porowatością, nadmierne zawilgocenie i zasolenie odnosi się do spoin wykonanych z zaprawy budowlanej.

Nadmierne zawilgocenie, o którym mowa, jest wynikiem bezpośredniego, długotrwałego kontaktu muru z gruntem wskutek braku poziomych i pionowych izolacji przeciwwilgociowych, których dawniej nie wykonywano. Wówczas zawarta w gruncie woda wraz $\mathrm{z}$ rozpuszczonymi w niej solami wnika stopniowo w mur i wskutek podciągania kapilarnego 
przemieszcza się w coraz wyższe jego partie zawilgacając i zasalając go (Rys. 1a), czego konsekwencją są zniszczenia tynku, cegieł i zaprawy (Rys. 1b).

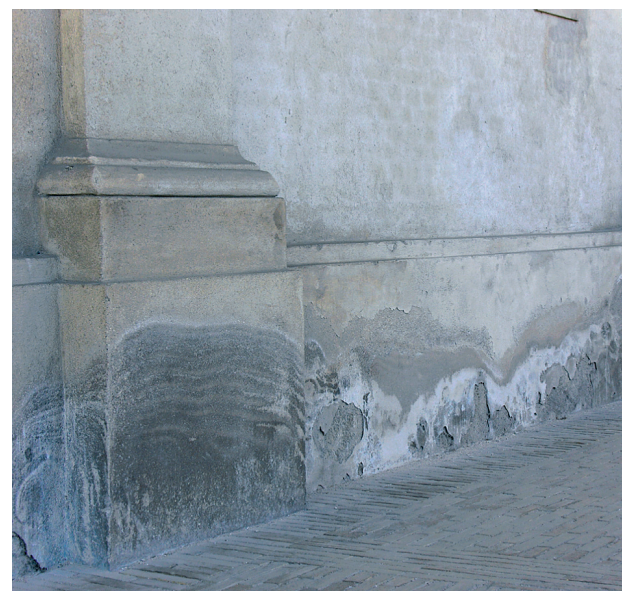

a)

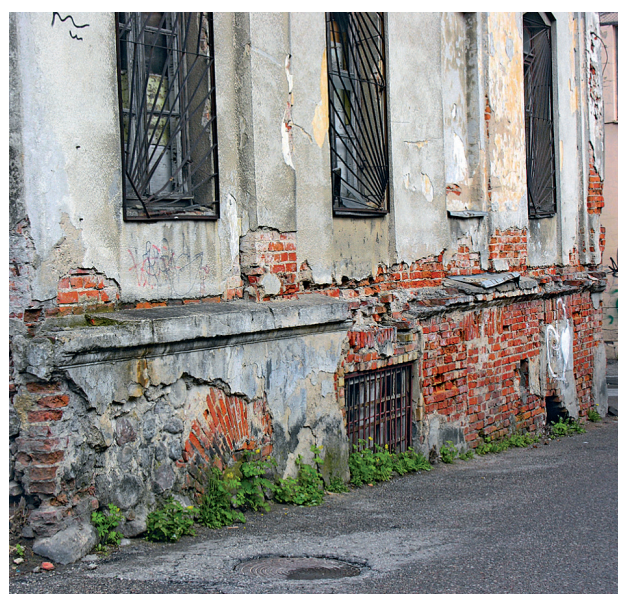

b)

Rys. 1. Przykładowy widok: a) postępującego procesu zawilgocenia i zasolenia; b) zniszczeń muru spowodowanych długotrwałym nadmiernym zawilgoceniem i zasoleniem

Warto w tym miejscu zwrócić uwagę na to, że wartościowe historycznie budynki mogą być użytkowane wyłącznie w sposób zgodny z zasadami opieki nad zabytkami. Obowiązkiem właścicieli jest właściwe ich utrzymanie oraz konserwacja, przy czym prace ingerujące w zabytkową tkankę podlegają rygorowi wcześniejszego uzyskanie pozwolenia od władz konserwatorskich $[2,3]$.

Mówiąc o nadmiernym zawilgoceniu murów warto w tym miejscu podać przyjęte w literaturze technicznej klasyfikacje, zarówno zawilgocenia [4-7], jak i zasolenia [8]. Klasyfikacje te zilustrowano rysunkami 2 i 3 . Jeżeli wilgotność masowa przekracza 5\% bezwzględnie konieczne jest podjęcie działań mających na celu jej obniżenie do poziomu dopuszczalnego, natomiast za dopuszczalne zasolenie uznaje się takie, którego stężenie nie przekracza niskich wartości pokazanych na rysunku 3 .

W celu powstrzymania procesów niszczących powodowanych nadmiernym zawilgoceniem, niezbędne jest w pierwszej kolejności wykonanie badań ustalających przyczyny i wielkości zawilgocenia oraz zasolenia. Należy zrozumieć, że badania te stanowią podstawę zarówno do wyboru optymalnej dla danej sytuacji metody wykonania zabezpieczenia przeciwwilgociowego, a następnie jej zaprojektowania i zrealizowania, są także punktem wyjścia do podjęcia decyzji odnośnie do dalszego postępowania z takim murem, czy to w zakresie jego osuszenia, czy też kontrolowania w późniejszych okresach skuteczności działania wykonanego zabezpieczenia.

Zamierzeniem autora niniejszego artykułu jest naświetlenie problematyki ujętej w tytule, w tym przede wszystkim uczulenie na negatywne skutki nadmiernego zawilgocenia i zasolenia, sukcesywnie pogarszające stan techniczny budynków, zwrócenie uwagi na uwarunkowania i użyteczne metody badania wilgotności w budynkach zabytkowych, w tym zasygnalizowanie możliwości wykorzystania do tego celu sztucznych sieci neuronowych, a także sprecyzowanie działań przyczyniających się do powstrzymywania postępującej degradacji i przywrócenia należytego stanu technicznego budynków zabytkowych. 


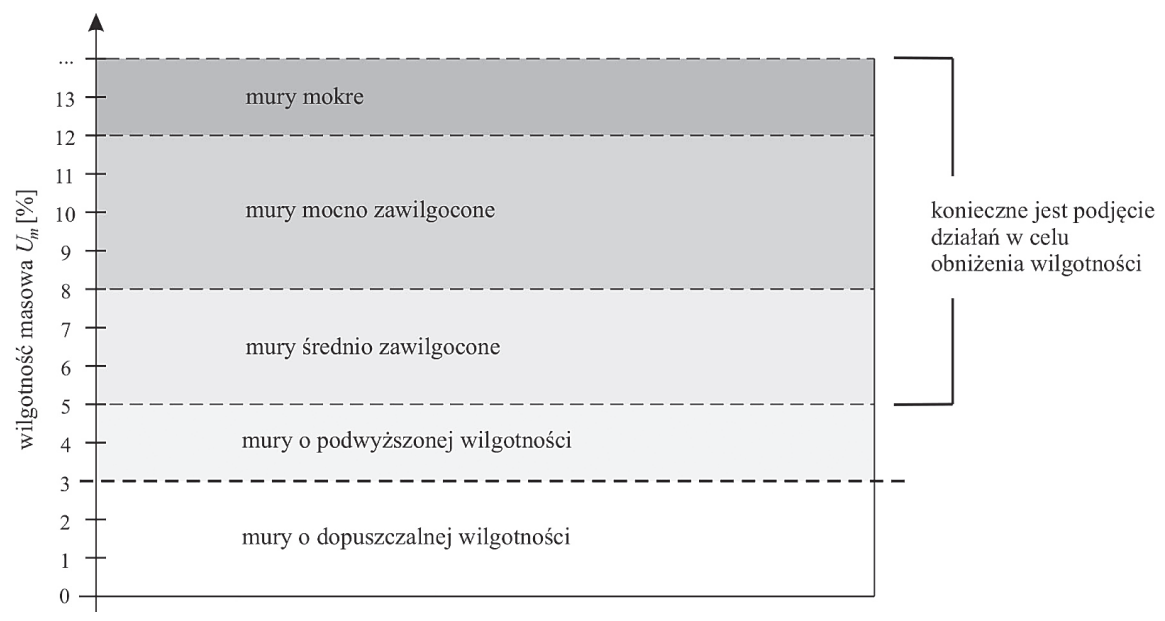

Rys. 2. Klasyfikacja zawilgocenia wg [7]

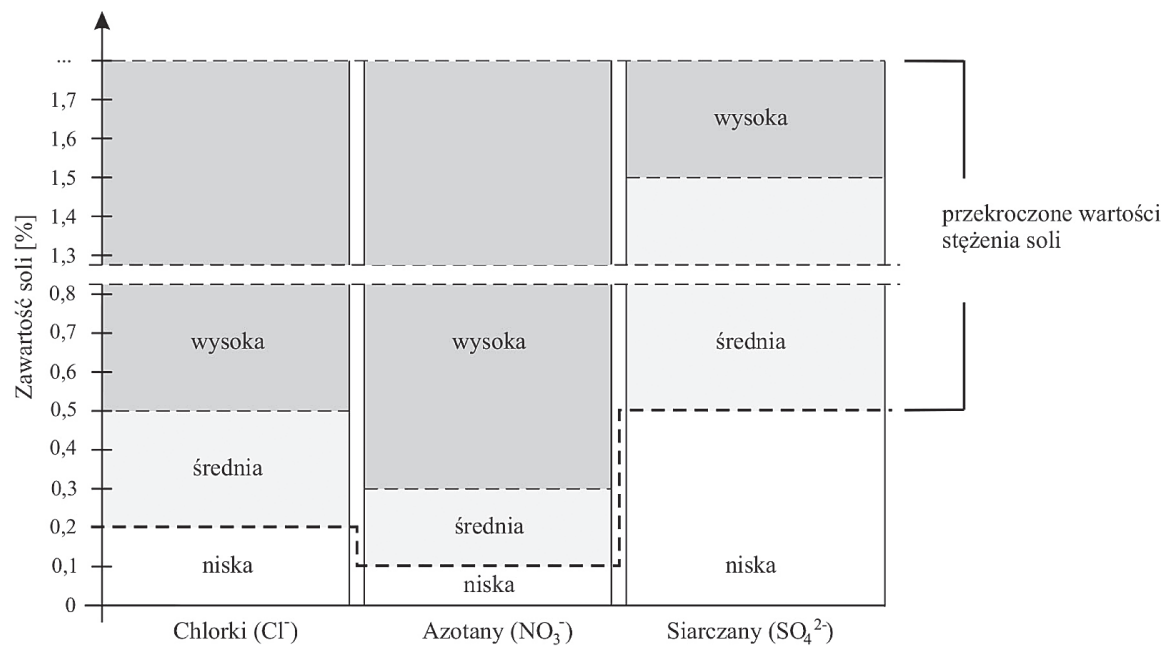

Rys. 3. Klasyfikacja zasolenia wg [9]

\section{Przyczyny i najważniejsze negatywne skutki nadmiernego zawilgocenia}

Budynek pozbawiony izolacji przeciwwilgociowych, co w przypadku obiektów zabytkowych zdarza się bardzo często, zawilgacany jest przede wszystkim wodą zawartą w gruncie, podciąganą kapilarnie. Występuje ona w postaci błonkowej - stanowiącej otoczkę ziaren gruntu, kapilarnej - wypełniającej pory w gruncie w wyniku napięcia powierzchniowego, a także gruntowej - pochodzącej głównie z opadów atmosferycznych przesiąkających przez górne warstwy gruntu. Do nadmiernego zawilgocenia przyczynia się także woda pochodząca z długotrwałego wykraplania pary wodnej na powierzchni wewnętrznej lub wewnątrz muru, wskutek niedostatecznej izolacyjności termicznej przegrody. Zawilgocenie potęgowane jest ponadto przez obecne w murze skrystalizowane sole, które higroskopijnie wchłaniają wilgoć 
z otaczającego powietrza. Jak znaczny może być tylko z tego powodu przyrost zawilgocenia muru ceglanego pokazuje rysunek 4 .

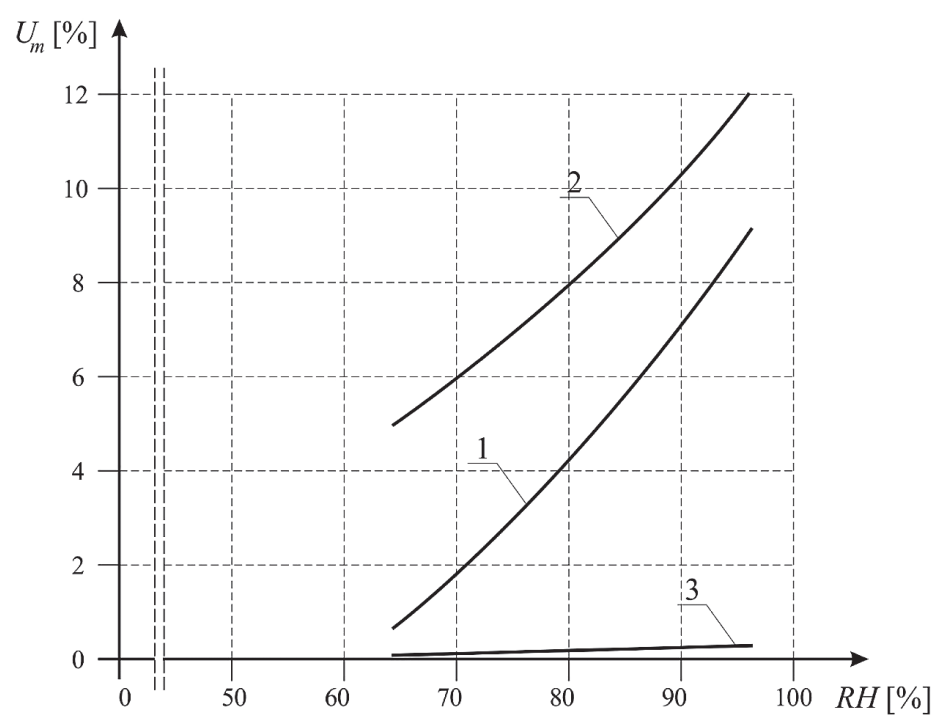

Rys. 4. Wzrost wilgotności masowej muru ceglanego spowodowany sorpcją wilgoci z powietrza w zależności od jego wilgotności względnej i rodzaju i stężenia soli w murze [10]: 1 - NaCL, $28 \mathrm{mg} / \mathrm{g}, 2-\mathrm{Ca}\left(\mathrm{OH}_{3}\right)_{2}, 100 \mathrm{mg} / \mathrm{g}, 3-$ mur nie zawierający soli

O zawilgoceniu muru decyduje przede wszystkim ilość zawartej w nim wody związanej fizyko-mechanicznie, a mianowicie zwilżalnej i kapilarnej oraz niezwiązanej, powstającej podczas kondensacji pary wodnej na powierzchni muru lub utrzymywanej siłami grawitacji w murze. Nie bez znaczenia jest także ilość wody związanej chemicznie przez skrystalizowane w murze sole.

Mechanizm transportu wilgoci w materiałach kapilarno-porowatych jest znany i opisany m.in. w pracach $[11,12,13]$. Zasadniczo, podciąganie kapilarne jest zjawiskiem występującym w materiałach hydrofilowych charakteryzujących się porami o promieniu mieszczącym się w przedziale od $10^{-1}$ do $10^{-4} \mathrm{~mm}$, a takie dominują w elementach składowych muru ceglanego [13]. Wysokość podciągania kapilarnego istotnie zależy od promienia porów kapilarnych, tzn. im mniejszy jest ten promień, tym wysokość podciągania jest większa. W wielu budynkach zabytkowych zawilgocenie ścian sięga nawet kilku metrów powyżej poziomu, na którym ściana styka się bezpośrednio z gruntem, co obrazuje rysunek 1.

Ważnym, negatywnym skutkiem nadmiernego zawilgocenia, z punktu widzenia bezpieczeństwa konstrukcji budynku, jest obniżenie wytrzymałości mechanicznej elementów składowych muru. Szczególnie zaprawa wapienna występująca w murach wielu budynków zabytkowych, wykonana na spoiwie ,powietrznym”, a nie na hydraulicznym, traci swoje walory wytrzymałościowe. Powyższe stwierdzenie dotyczy także zapraw wykonanych na bazie cementu. Taka obniżona wytrzymałość może skutkować deformacjami i spękaniami muru. Przykładowo, na rysunku 5 pokazano schemat ilustrujący stopniową zmianę wytrzymałości na ściskanie muru ceglanego wskutek zmiany w czasie jego stanu wilgotnościowego. Rysunek ten sporządzono przy założeniu, że w międzyczasie nie doszło do destrukcji mrozowej zawilgoconego muru. 


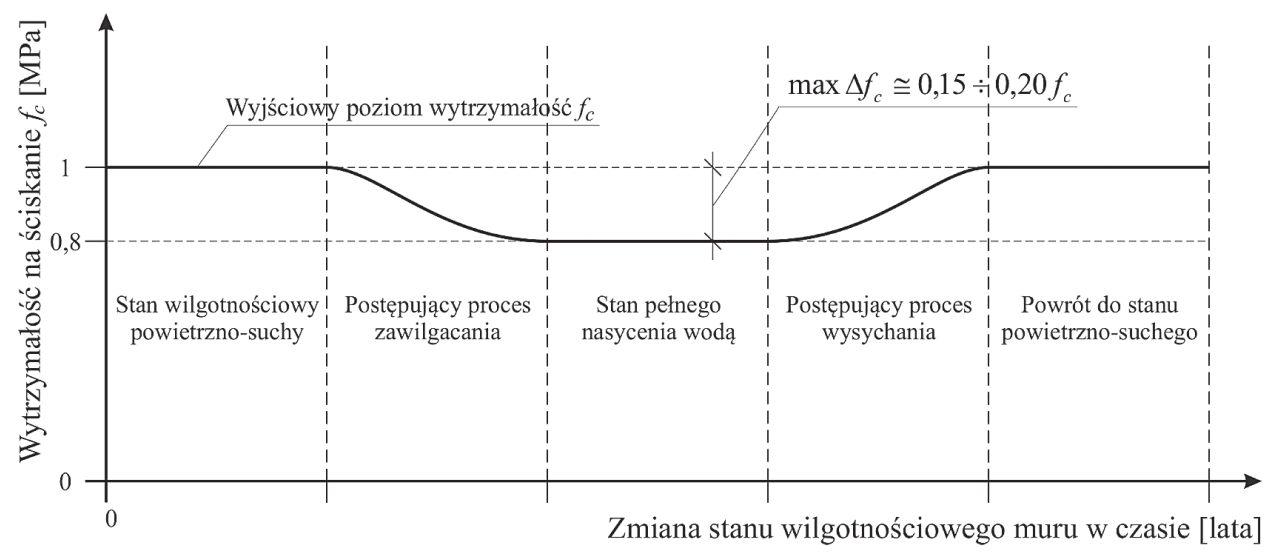

Rys. 5. Schemat ilustrujący stopniową zmianę wytrzymałości na ściskanie muru wskutek zmiany w czasie jego stanu wilgotnościowego

Negatywne skutki nadmiernego zawilgocenia polegające na obniżeniu wytrzymałości mechanicznej muru potęgowane są destrukcyjnym wpływem soli rozpuszczalnych w wodzie, które wskutek procesów krystalizacji i hydratacji, zachodzących w przypowierzchniowej strefie muru i na jego powierzchni (w tej strefie najintensywniej przebiega proces wysychania wilgoci), rozsadzają strukturę muru oraz tworzą powierzchniowe wykwity solne. Sole, o których mowa, a są to głównie siarczany, chlorki, azotany i węglany, są wszechobecne w środowisku otaczającym budynki. Ich pochodzenie w części jest naturalne, a w części jest efektem działalności człowieka skutkującej zanieczyszczeniem środowiska, np. poprzez nawożenie gruntów nawozami sztucznymi, stosowanie chemicznych środków ochrony roślin, czy odladzanie dróg i ulic. Rysunek 6 ilustruje przykładowo charakterystyczne strefy krystalizacji soli na różnej wysokości ściany murowanej.

a)

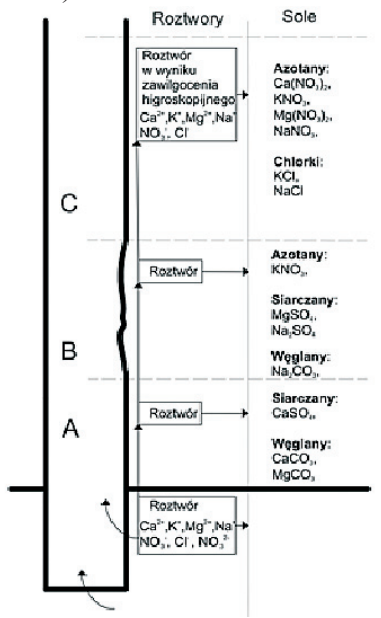

b)

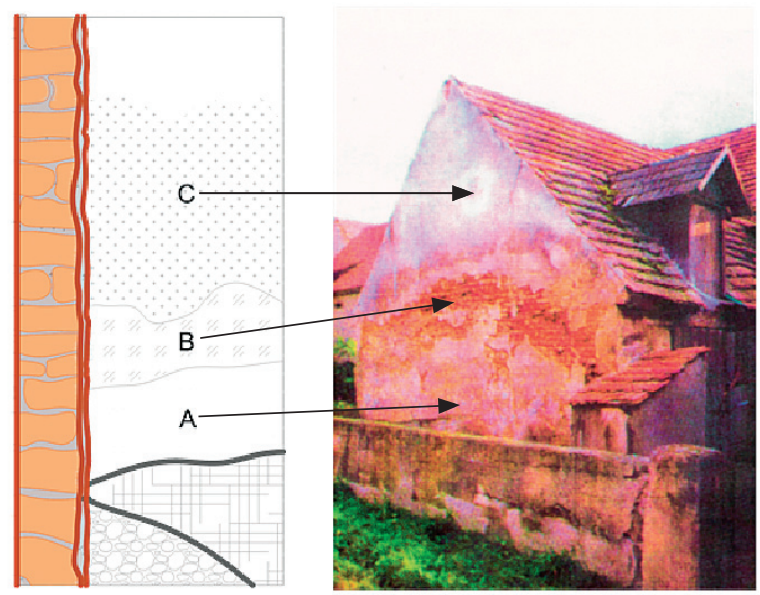

Rys. 6. Obrazy przedstawiające wg [14]: a) wnikanie roztworów wodnych z charakterystycznymi strefami rozkładu soli w strukturze i na powierzchni muru; b) strefy krystalizacji soli na różnej wysokości ściany; c) ścianę budynku z widocznymi charakterystycznymi strefami krystalizacji soli 
Mechanizm szkodliwego oddziaływania soli na materiały budowlane został zdaniem autora niniejszej publikacji bardzo jasno przedstawiony w $[15,16,17]$. Nie rozpisując się wiec na ten temat szerzej, wskazano główne przyczyny zniszczeń struktury muru spowodowanych obecnością w nim soli rozpuszczalnych w wodzie, którymi są procesy krystalizacyjne i hydratacyjne.

Do krystalizacji dochodzi wtedy, kiedy wraz ze wzrostem stężenia soli w wodzie roztwór staje się przesycony. Procesy krystalizacyjne postępują w sposób ciągły, co znaczy, że po zapełnieniu się porów kryształami soli krystalizacja postępuje nadal, ale ponieważ wzrost kryształów jest uniemożliwiony przez ścianki porów, dochodzi do narastania ciśnienia na te ścianki. Po przekroczeniu wytrzymałości na rozciąganie cegły lub zaprawy (generalnie muru) następuje rozerwanie struktury. Ciśnienie krystalizacyjne zależy głównie od temperatury $T$, molowej objętości soli, i od stosunku stężenia soli w stanie przesyconym $C$ do stężenia soli w stanie nasyconym $C_{s .}$ Jak duże mogą być wartości tego ciśnienia ilustruje tablica 1 .

Tabela 1. Wartości ciśnienia krystalizacyjnego dla wybranych przykładowo kilku soli rozpuszczalnych $\mathrm{w}$ wodzie, na podstawie $[5,17,18]$

\begin{tabular}{|c|c|c|c|c|c|c|}
\hline \multirow{3}{*}{ Lp. } & \multirow{3}{*}{ Sól } & \multirow{3}{*}{$\begin{array}{c}\text { Objętość } \\
\text { molowa } \\
{\left[\mathrm{cm}^{3} / \mathrm{mol}\right]}\end{array}$} & \multicolumn{4}{|c|}{ Ciśnienie krystalizacyjne [MPa] } \\
\hline & & & \multicolumn{2}{|c|}{$C / C_{s}=2$} & \multicolumn{2}{|c|}{$C / C_{s}=10$} \\
\hline & & & $T=0^{\circ} \mathrm{C}$ & $T=20^{\circ} \mathrm{C}$ & $T=0^{\circ} \mathrm{C}$ & $T=20^{\circ} \mathrm{C}$ \\
\hline & Soda $\left(\mathrm{Na}_{2} \mathrm{CO}_{3} \cdot 10 \mathrm{H}_{2} \mathrm{O}\right)$ & 199 & 7,9 & 8,5 & 26,3 & 28,2 \\
\hline 2. & Sól gorzka $\left(\mathrm{MgSO}_{4} \cdot 7 \mathrm{H}_{2} \mathrm{O}\right)$ & 147 & 10,7 & 11,5 & 35,6 & 38,2 \\
\hline & Gips $\left(\mathrm{CaSO}_{4} \cdot 2 \mathrm{H}_{2} \mathrm{O}\right)$ & 54 & 29,1 & 31,3 & 96,8 & 103,9 \\
\hline & Anhydryt $\left(\mathrm{CaSO}_{4}\right)$ & 46 & 34,2 & 36,7 & 113,6 & 121,9 \\
\hline 5. & Halit $(\mathrm{NaCl})$ & 28 & 56,5 & 60,6 & 187,7 & 201,4 \\
\hline
\end{tabular}

W przypadku soli posiadających zdolność do hydratacji, ciśnienie krystalizacyjne jest potęgowane, ponieważ przyłączanie cząsteczek wody przez kryształy soli budujących sole uwodnione powoduje wzrost objętości [17]. Parametrami sterującymi procesem uwodnienia są wilgotność i temperatura w tym rozumieniu, że równoczesny wzrost wilgotności i spadek temperatury intensyfikują proces hydratacji.

Jeżeli porówna się wartości ciśnień krystalizacyjnych podane w tablicy $1 \mathrm{z}$ wytrzymałością na rozciąganie cegły ceramicznej, wynoszącej maksymalnie do około 4,0 MPa, i wytrzymałością na rozciąganie zaprawy wapiennej, zazwyczaj niższą od 1,0 MPa, to staje się jasne, dlaczego dochodzi do rozsadzania struktury muru w strefie przypowierzchniowej. Opisaną sytuację obrazuje rysunek 7.

Nadmierne zawilgocenie muru wpływa także negatywnie na własności cieplne wbudowanych w niego materiałów powodując wzrost współczynnika przewodzenia ciepła. Prostą tego konsekwencją jest zmniejszenie izolacyjności termicznej przegrody zewnętrznej. Bardzo często dochodzi z tego powodu do kondensowania się pary wodnej na powierzchni wewnętrznej albo wewnątrz muru, czego konsekwencją jest jeszcze większe zawilgocenie przegrody. Ilustracją powyższych stwierdzeń jest rysunek 8 , na którym za [10, 19] pokazano wpływ zawilgocenia na przewodność cieplną wybranych materiałów stosowanych do budowy murów oraz rysunek 9, który obrazuje wpływ wzrostu wilgotności masowej muru na zmniejszenie izolacyjności termicznej. 


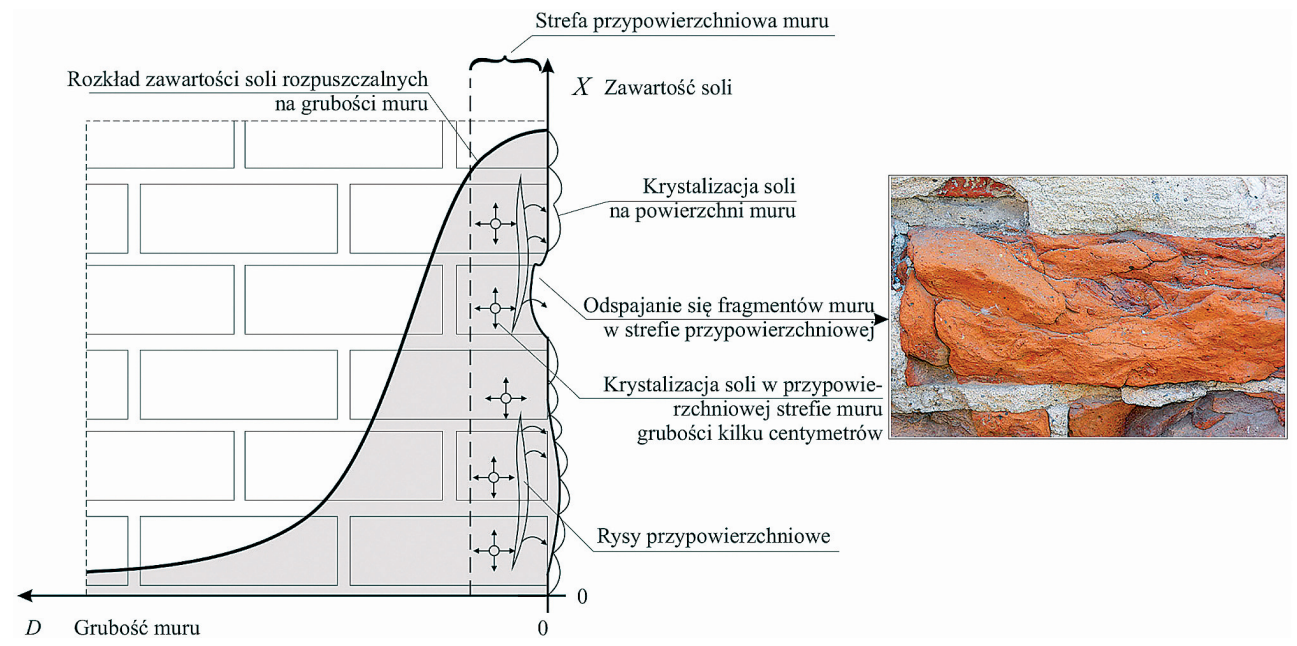

Rys. 7. Typowy rozkład zawartości soli rozpuszczalnych w wodzie na grubości muru w połączeniu $\mathrm{z}$ mechanizmem niszczenia muru w strefie przypowierzchniowej

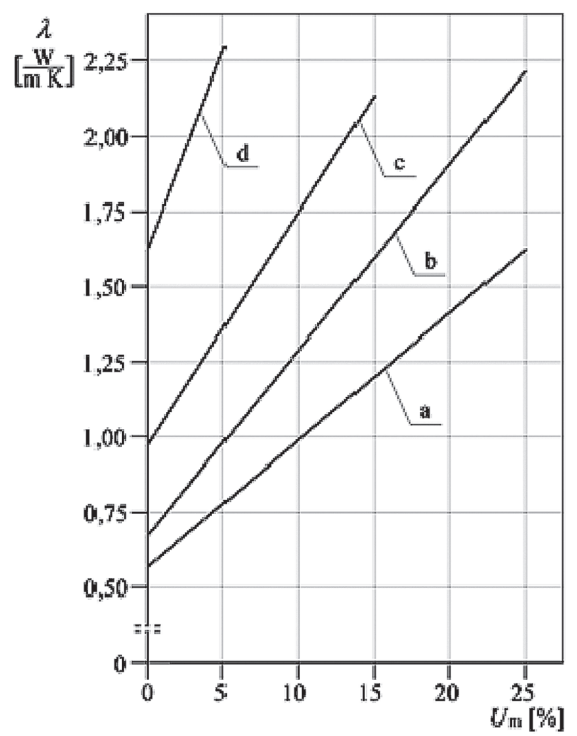

Rys. 8. Wpływ zawilgocenia na przewodność cieplną wybranych materiałów budowlanych [10, 19]: a - cegła ceramiczna o gęstości około $1700 \mathrm{~kg} / \mathrm{m}^{3}, \mathrm{~b}$ - cegła ceramiczna o gęstości około $1800 \mathrm{~kg} / \mathrm{m}^{3}$, c - wapień o gęstości około $1950 \mathrm{~kg} / \mathrm{m}^{3}, \mathrm{~d}-$ cegła klinkierowa

Konsekwencją pogorszenia właściwości cieplnych przegrody, spowodowanego nadmiernym zawilgoceniem, jest pogorszenie warunków eksploatacyjnych w pomieszczeniach. Przejawia się to nie tylko kondensującą się na powierzchni wewnętrznej przegrody parą wodną, ale także związanym z tym rozwojem grzybów pleśniowych i domowych, szkodliwych dla zdrowia człowieka [20]. Uszkodzeniu ulegają wówczas tynki, od powierzchni ścian odspajają się i odpadają powłoki malarskie, a co za tym idzie zniszczeniu ulegają m.in. wykonane na tych tynkach historyczne malowidła. 


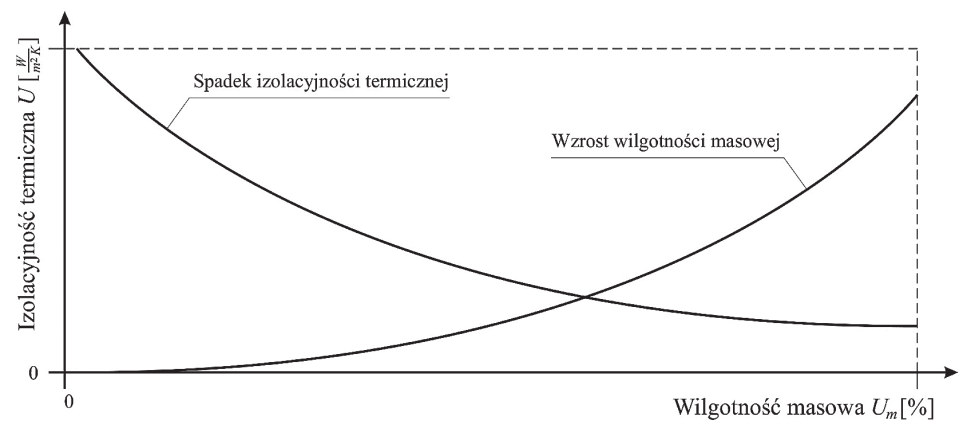

Rys. 9. Zależność spadku izolacyjności termicznej przegrody od wzrostu wilgotności masowej muru

\section{Przegląd metod badania wilgotności - uwarunkowania badań}

Metody badania wilgotności dzielą się na dwie grupy, niszczące - wymagające pobrania próbek materiału do badań oraz nieniszczące - niewymagające ingerencji w strukturę materiału [10, 14]. Ich klasyfikację przestawiono na schemacie, na rysunku 10.

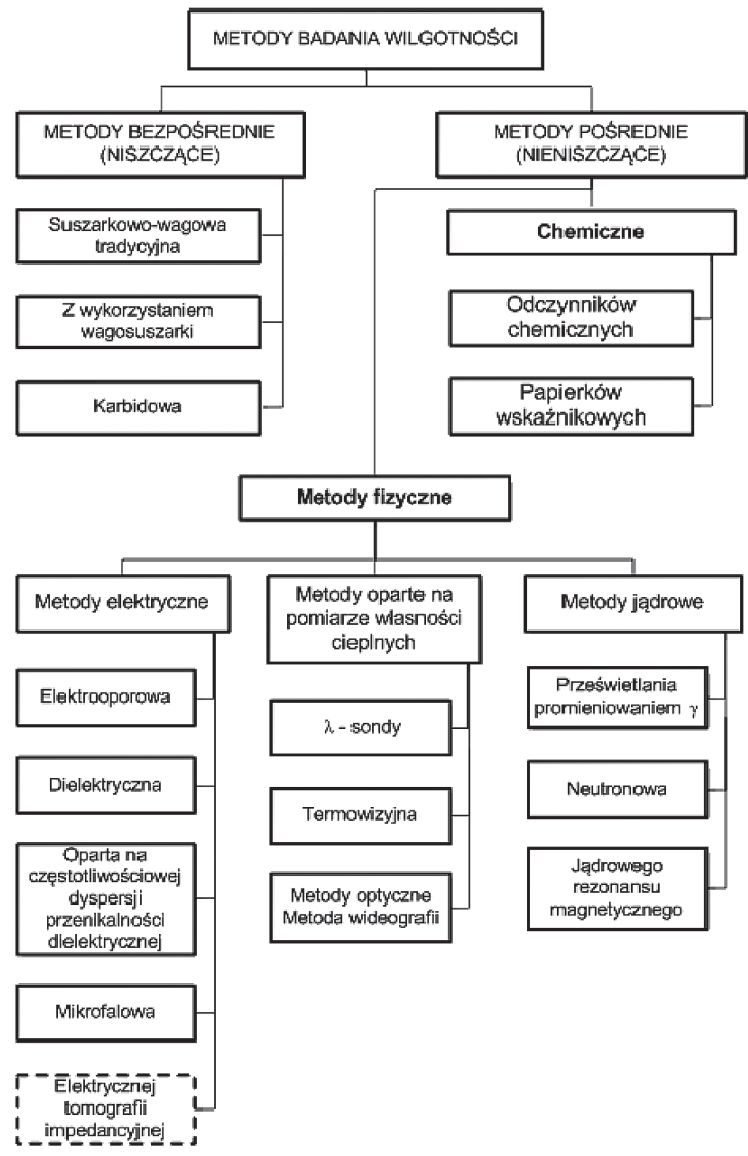

Rys. 10. Podział metod badania wilgotności materiałów i przegród budowlanych, za $[10,14]$ 
Ponieważ w przypadku obiektów zabytkowych pobieranie próbek do badań możliwe jest tylko w bardzo ograniczonym zakresie, do badań wilgotności prowadzonych w takich budynkach predysponowane są metody nieniszczące. Z rysunku 10 wynika, że metod tych jest wiele. Należy mieć jednak na uwadze to, że metody nieniszczące mają pewne ograniczenia, które powodują, że ich stosowanie w budynkach zabytkowych staje się problematyczne. Ponadto nie wszystkie pozwalają w sposób ilościowy ocenić wilgotność i jej rozkład w przegrodzie. Niewątpliwie zaletą metod nieniszczących jest brak ingerencji w strukturę materiału podczas prowadzenia badań, a co za tym idzie możliwość wykonania badań w dowolnej liczbie miejsc badawczych [7].

I tak, cześć z metod nieniszczących pozwala ocenić wilgotność wyłącznie w sposób jakościowy, nie ilościowy. Jak to wyjaśniono w [7, 14], odnosi się to do chemicznej metody papierków wskaźnikowych w przypadku której zawilgocenie określane jest obrazowo na podstawie zmiany zabarwienia papierków wskutek kontaktu z powierzchnią zawilgoconego materiału. Podobnie rzecz ma się z metodami opartymi na pomiarze właściwości cieplnych, termowizyjnej, optycznych i wideografii. Są one przydatne jedynie do lokalizowania wilgotnych obszarów przegrody, bez możliwości określania wartości wilgotności. Jest to istotne ograniczenie. Z kolei metody jądrowe, ze względu na uwarunkowania aparaturowe i wysokie koszty prowadzenia badań praktycznie nie są stosowane w warunkach in situ. Podobnie rzecz ma się z metodą elektrycznej tomografii impedancyjnej, która umożliwia uzyskanie przestrzennego rozkładu wilgotności w przegrodzie, jednak z braku produkowanej seryjnie aparatury nie może być stosowana w praktyce [7]. Również, zaliczana do grupy metod elektrycznych metoda opornościowa ma istotny mankament, bo wymaga wprowadzania elektrod igłowych bezpośrednio do badanego materiału w wywiercone w nim liczne otwory o niewielkiej średnicy [7]. Ta konieczna ingerencja w strukturę materiału przegrody powoduje, że metoda nie może być polecana w badaniach wilgotności w obiektach zabytkowych.

Za najbardziej przydatne na chwilę obecną uznaje się metody elektryczne, dielektryczną i mikrofalową. W przypadku metody dielektrycznej wykorzystywane jest zjawisko zmiany stałej dielektrycznej badanego materiału wskutek zawilgocenia, natomiast w metodzie mikrofalowej mierzone jest tłumienie mikrofal przechodzących przez zawilgocony materiał. Oznacza to, że w przypadku obydwu metod podczas wykonywania badań nie mierzona jest bezpośrednio wilgotność, lecz inna fizyczna cecha materiału na wartość której wpływa zawarta w nim woda. Rezultatem pomiaru jest więc parametr niemianowany $X$. Dlatego też, do określenia wartości wilgotności niezbędne jest skalowanie aparatury na danym obiekcie w wyniku którego określona zostaje zależność korelacyjna lub hipotetyczna, między mierzonym parametrem bezwymiarowym $X$ a na przykład wilgotnością masową $U_{m}$. Bez względu na sposób określenia tej zależności, co wyjaśnia rysunek 11 [7], niezbędne jest pobranie pewnej minimalnej liczby próbek do badań laboratoryjnych prowadzonych metodą suszarkowo-wagową.

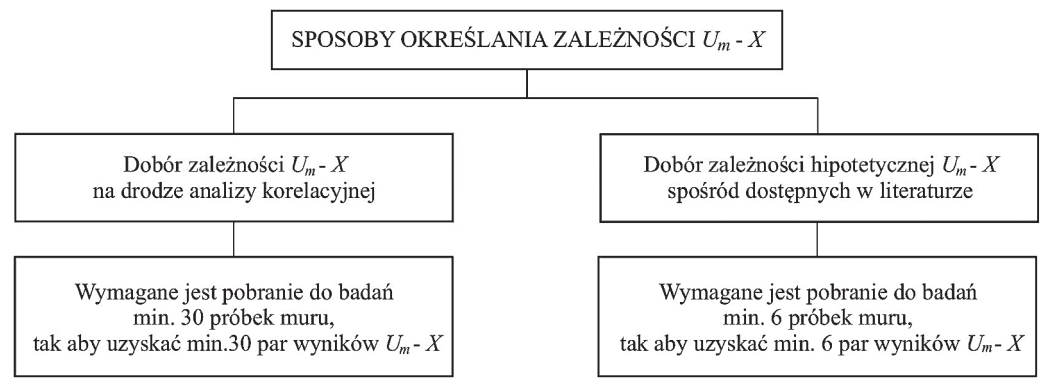

Rys. 11. Sposoby określenia zależności $U_{m}-X$ dla użytej w badaniach metody nieniszczącej dielektrycznej lub mikrofalowej, za [7] 
Jak to zauważono w $[7,14]$, brak zgody służb konserwatorskich na pobranie próbek do badań, lub niewiedza badającego wilgotność powoduje, że procedura skalowania aparatury badawczej na obiekcie jest pomijana. W zamian tego korzysta się ze skalowania wykonanego w laboratorium, przez producenta aparatury. Skalowanie takie odbywa się prawie zawsze na podstawie badania próbek zawilgoconych wodą pozbawioną rozpuszczalnych $\mathrm{w}$ niej soli. $\mathrm{Na}$ podstawie przeprowadzonych $\mathrm{w}$ [14] szerokich badań opublikowanych m.in. w [21, 22, 23] wynika natomiast jednoznacznie, że zasolenie istotnie wpływa na rezultaty badań uzyskane metodami elektrycznymi powodując zawyżenie ocenianej wartości wilgotności w porównaniu do wilgotności rzeczywistej. Ponieważ w przypadku budynków historycznych zawsze mamy do czynienia z murami zasolonymi, rezultaty uzyskane z wykorzystaniem aparatury wyskalowanej poza badanym obiektem mogą znacznie odbiegać od rzeczywistości, co ilustrują rysunki 12 i 13 .

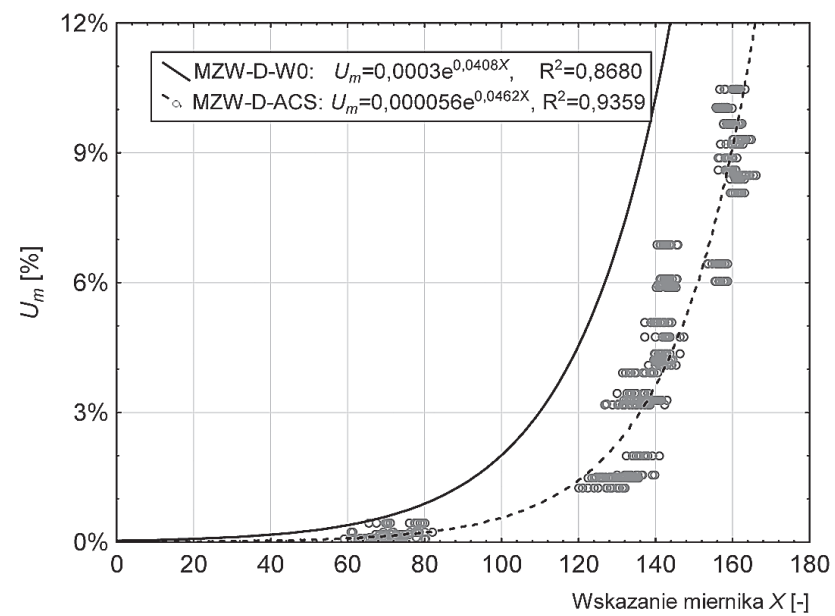

Rys. 12. Zbiorcza zależność między wilgotnością masową $U_{m}$ a wskazaniem $X$ miernika dielektrycznego dla murów ceglanych wykonanych na zaprawie wapiennej (MZW) przechowywanych w środowiskach wodnych: azotanowym (A), chlorkowym (C) i siarczanowym (S), na tle zależności otrzymanej dla tych murów przechowywanych w wodzie destylowanej (WO), wg [14]

Warto w tym miejscu powiedzieć, że problem wiarygodnej oceny nieniszczącymi metodami elektrycznymi zawilgocenia zasolonych murów ceglanych w budynkach zabytkowych może zostać w najbliższym czasie skutecznie rozwiązany z pomocą sztucznych sieci neuronowych. Wyeliminuje to kłopotliwą każdorazową konieczność skalowania aparatury na danym obiekcie. Na chwilę obecna wykazano na podstawie badań testowych murów ceglanych, przechowywanych w warunkach laboratoryjnych w środowisku wodnym siarczanowym, chlorkowym i azotanowym oraz w środowisku wodnym pozbawionym soli jako porównawczym, że sztuczna sieć neuronowa jednokierunkowa wielowarstwowa ze wsteczną propagacja błędu o odpowiednio dobranej strukturze i algorytmie uczenia Broyden-Fletcher-Goldfarb-Shanno jest do ego celu predysponowana $[14,24]$. Sieć ta została nauczona i przetestowana na zbudowanej do tego celu bazie składającej się z ponad 1000 zestawów wyników. W skład każdego zestawu weszły: dwa parametry bezwymiarowe $X_{D}$ i $X_{M}$ opisujące zawilgocenie badanych murów testowych określone odpowiednio metodą dielektryczną i mikrofalową, trzy pomocnicze parametry $A, C, S$ opisujące stężenie soli (w \%) występujących w tych murach przechowywanych $\mathrm{w}$ środowisku wodnym odpowiednio azotanowym i chlorkowym oraz siarczanowym, oraz parametr $U_{m}$ opisujący rzeczywistą wilgotność masową muru (w \%) ustaloną metodą su- 
szarkowo-wagową. Na rysunku 14 pokazano, za [24], strukturę sztucznej sieci neuronowej jednokierunkowej, wielowarstwowej z 11 neuronami w warstwie ukrytej.

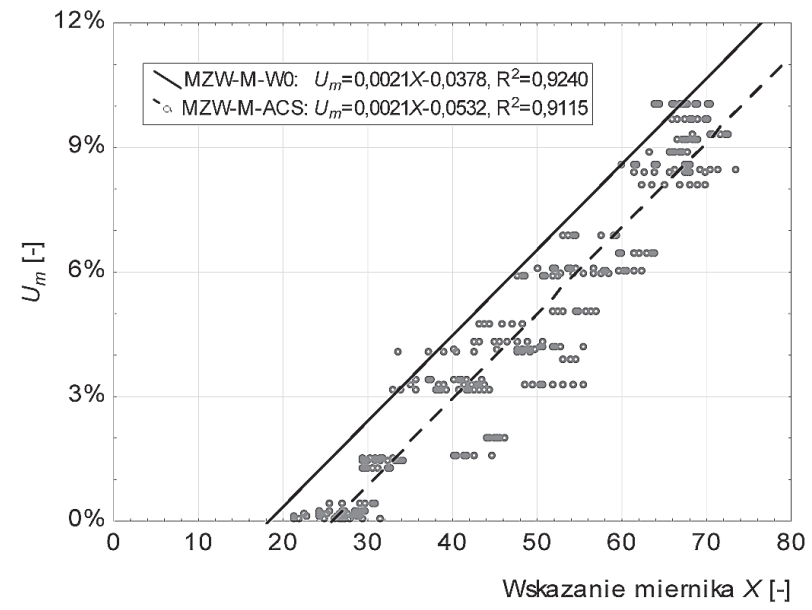

Rys. 13. Zbiorcza zależność korelacyjna między wilgotnością masową $U_{m}$ a wskazaniem $X$ miernika mikrofalowego dla murów ceglanych wykonanych na zaprawie wapiennej (MZW) przechowywanych w środowiskach wodnych: azotanowym (A), chlorkowym (C) i siarczanowym (S), na tle zależności otrzymanej dla tych murów przechowywanych w wodzie destylowanej (WO), wg [14]

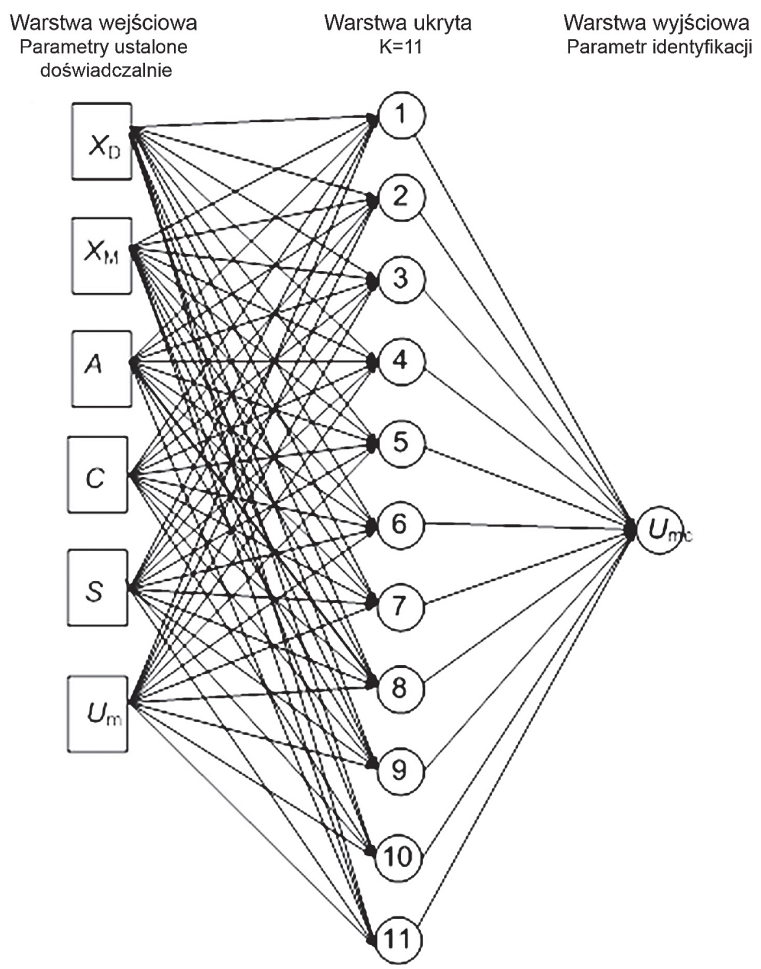

Rys. 14. Struktura sztucznej sieci neuronowej jednokierunkowej wielowarstwowej, predysponowanej do oceny wilgotności masowej $U_{m c}[24]$ 
O przydatności tej sieci do wiarygodnej oceny wilgotności zasolonego muru ceglanego świadczą uzyskane bardzo wysokie wartości współczynnika korekcji liniowej $R$ zarówno dla procesu uczenia, testowania jak i weryfikacji doświadczalnej, uwidocznione na rysunku 15 [14]. Aby ten sposób oceny wilgotności mógł wejść do praktyki budowlanej konieczna jest jednak jego weryfikacja na obiektach zabytkowych.

a)

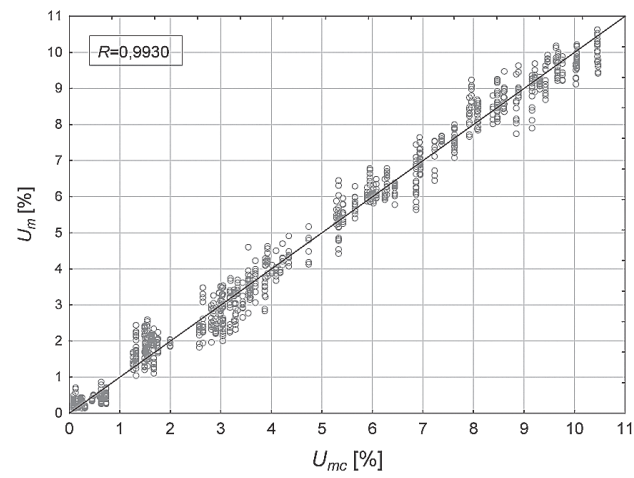

b)

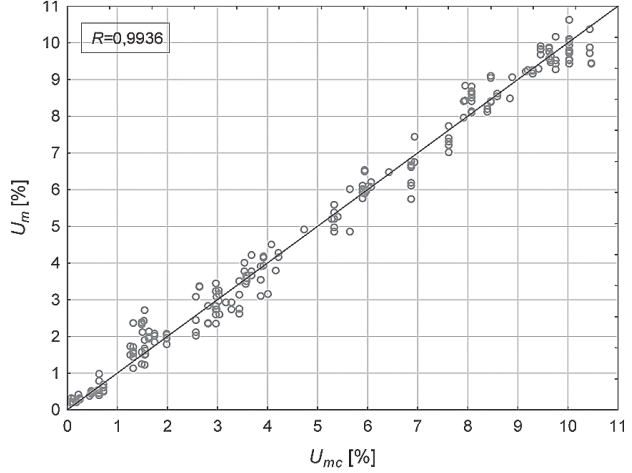

c)

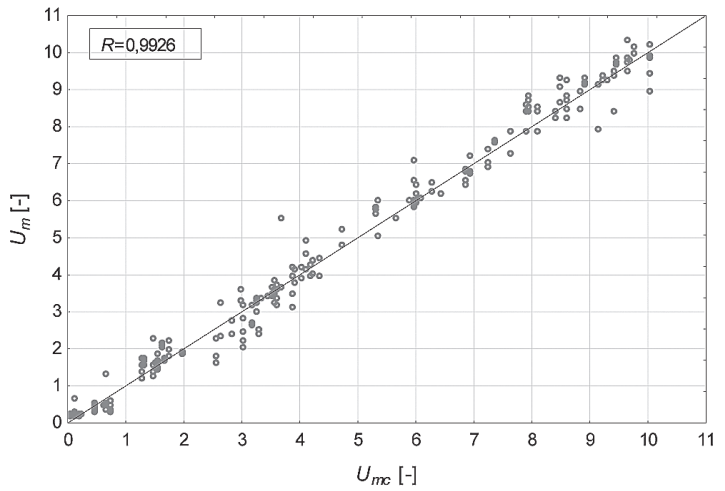

Rys. 15. Zależność między wilgotnością masową $U_{m}$ badanych testowych murów ceglanych uzyskana metodą suszarkowo-wagową i wilgotności $U_{m c}$ identyfikowana przez sztuczną sieć neuronową dla procesu $[14,24]$ a) uczenia, b) testowania, c) weryfikacji doświadczalnej

Ponadto uwagi wymaga jeszcze jeden problem. Otóż w wielu budynkach zabytkowych ściany murowane mają znaczną grubość, nierzadko przekraczająca 100 i więcej centymetrów. Tymczasem zasięg metod nieniszczących jest zdecydowanie mniejszy i wynosi w przypadku metody dielektrycznej około $60 \mathrm{~mm}$ i do około $300 \mathrm{~mm}$ dla metody mikrofalowej. Jeżeli informacje te skonfrontuje się z rysunkiem, na którym pokazany został typowy rozkład wilgotności masowej na grubości muru to staje się jasne, że aby uzyskać pełny obraz zawilgocenia przegrody niezbędne jest wykonanie przez nią przynajmniej jednego kontrolnego lub kilku kontrolnych przewiertów. Przewierty te powinny być wykonane przynajmniej do połowy grubości przegrody celem pobrania próbek do badań laboratoryjnych niezbędnych do ustalenia rozkładu wilgotności na grubości muru. 


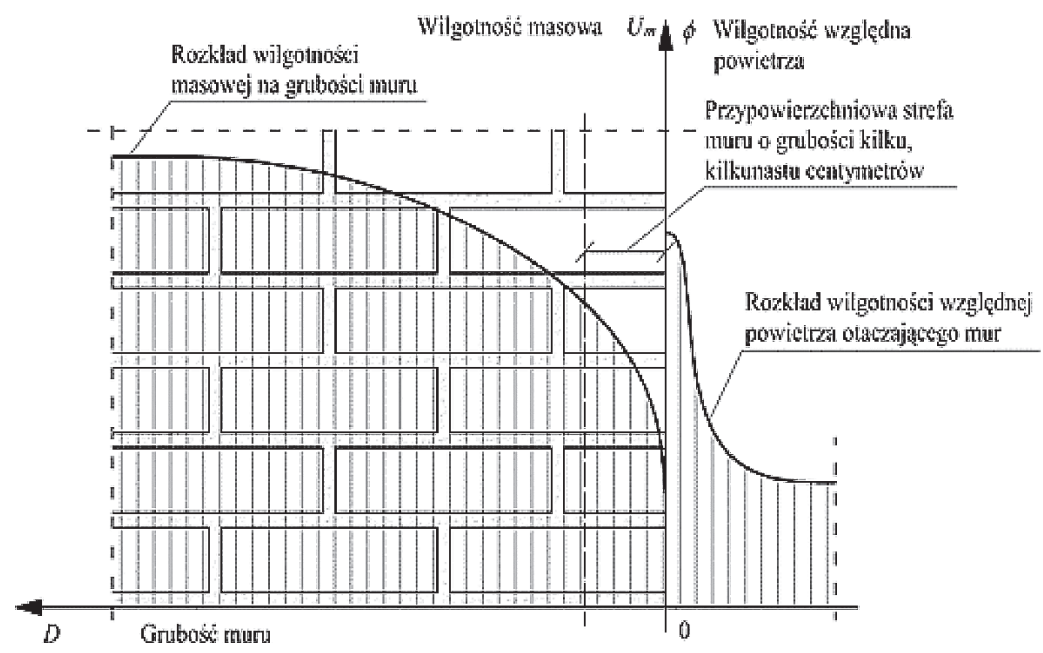

Rys. 16. Typowy rozkład wilgotności masowej na grubości muru wg [10,14]

W zakończeniu tego punktu warto podkreślić, że jeżeli sygnalizowana powyżej konieczność pobierania z obiektu pewnej minimalnej liczby próbek zawilgoconych materiałów do badań laboratoryjnych spotka się ze zrozumieniem służb konserwatorskich, to bardzo korzystnie wpłynie to na wiarygodność rezultatów badań uzyskanych metodami nieniszczącymi, w tym na oszacowanie ilości wody zawartej w przegrodzie koniecznej do usunięcia, celem jej osuszenia.

\section{Przeciwdziałanie degradacji - ujęcie sygnalne}

Początkiem całego szeregu działań zapobiegających postępującej degradacji budynków zabytkowych wskutek nadmiernego zawilgocenia jest należyte zdiagnozowanie aktualnego stanu budynku i zidentyfikowanie otaczającego go środowiska. W zakresie tych działań mieści się między innymi: identyfikacja podłoża gruntowego i panujących w nim stosunków wodnych, ustalenie przyczyn nadmiernego zawilgocenia, określenie na podstawie specjalistycznych badań stopnia zawilgocenia i jego rozkładu po obwodzie oraz na wysokości i na grubości ścian wraz z ustaleniem stopnia zasolenia i rodzaju soli rozpuszczalnych w wodzie, zdiagnozowanie stanu technicznego zawilgoconych ścian wraz z ustaleniem ich rzeczywistej grubości oraz budowy w rozumieniu jednorodności materiałowej, identyfikacja cennych detali historycznych i malowideł, badania stratygraficzne, itp.

Wymienione wyżej działania stanowią podstawę wyjściową do sporządzenia dokumentacji projektowej, na którą składają się przede wszystkim projekt budowlany i wykonawczy, a następnie zrealizowanie na jej podstawie skutecznych zabezpieczeń przeciwwilgociowych poziomych i pionowych oraz innych prac budowlanych, w tym renowacyjnych, przywracających należyty stan techniczny budynku. Do zadań projektanta należy, po przeanalizowaniu danego przypadku zaprojektowanie optymalnych rozwiązań odnośnie do wykonania skutecznych poziomych i pionowych zabezpieczeń przeciwwilgociowych, dobór optymalnej metody osuszenia zabezpieczonych przeciwwilgociowo przegród do poziomu dopuszczalnego, zdecydowanie o wyborze sposobu „obróbki” soli, itd. 
Wszystkie te działania powinny być konsultowane i realizowane pod nadzorem służb konserwatorskich. Natomiast niewątpliwie jednym z najtrudniejszych zadań wykonawczych jest zrealizowanie $\mathrm{w}$ istniejącym budynku zabytkowym skutecznych poziomych zabezpieczeń przeciwwilgociowych. Jest to duże wyzwanie zwłaszcza wtedy, gdy ściany budynku są grube lub bardzo grube, czyli te, których grubość wynosi odpowiednio ponad $100 \mathrm{~cm}$ i ponad $200 \mathrm{~cm}$. Zarówno prace projektowe jak i wykonawcze zaliczają się do wysoce specjalistycznych, dlatego bardzo wskazane jest aby były realizowane przez osoby i firmy posiadające udokumentowane w tym zakresie doświadczenie.

Zdaniem autora szersze omówienie zasygnalizowanych powyżej bardzo ważnych zagadnień jest jak najbardziej uzasadnione, ale nie pozwalają na to ramy objętościowe niniejszej pracy. W tej sytuacji warto przynajmniej polecić w tym miejscu te prace $[5,10,25-30]$, w których zagadnieniom tym poświęcono dużo uwagi.

\section{Podsumowanie}

Podniesiona w artykule problematyka dotycząca degradacji budynków zabytkowych powodowanej nadmiernym zawilgoceniem i zasoleniem jest zdaniem autora aktualna, w odniesieniu do znacznej części budynków wartościowych historycznie i to w wielu krajach europejskich. Chodzi przede wszystkim o budynki o ścianach murowanych z cegły ceramicznej stosowanej w przeszłości powszechnie, nie posiadających izolacji przeciwwilgociowych, których dawniej nie wykonywano.

Omawiając negatywne skutki nadmiernego zawilgocenia i zasolenia, powodujące sukcesywne pogarszanie się stanu technicznego budynku, starano się zwrócić w artykule uwagę na mogące wystąpić z tego powodu obniżenie bezpieczeństwa konstrukcji oraz pogorszenie izolacyjności termicznej przegród i warunków eksploatacyjnych w pomieszczeniach. Z kolei, dokonując przeglądu metod badania wilgotności, z myślą o wyeliminowaniu ich bezkrytycznego stosowania, omówiono uwarunkowania badań wilgotności i wskazano użyteczne metody w odniesieniu do budynków zabytkowych.

Problemy przeciwdziałania degradacji budynków zabytkowych wskutek nadmiernego zawilgocenia potraktowano w pracy sygnalnie nie dlatego, że są one mało ważne. Wręcz przeciwnie, podkreślono ich ważność i wagę działań zapobiegających postępującej degradacji. Działania te starano się sprecyzować w ujęciu chronologicznym. Z uwagi na ograniczoną objętość niniejszego artykułu zrekompensowano ten niedobór czytelnikowi wskazując pozycje literaturowe, w tym książkowe, w których problemom tym poświęcono sporo miejsca.

\section{Literatura}

[1] Wójcik R., Tunkiewicz M. Pory butelkowe - charakterystyka, sposoby wyznaczania na przykładzie zaprawy cementowo-wapiennej. Materiały Budowlane 10 (2017) 57-59.

[2] Ustawa z dnia 23 lipca 2003 r. o ochronie zabytków i opiece nad zabytkami. Dz. U. nr 162, poz. 1568 z późniejszymi zmianami.

[3] Rozporządzenie Ministra Kultury z dnia 9 czerwca 2004 r. w sprawie prowadzenia prac konserwatorskich, restauratorskich, robót budowlanych, badań konserwatorskich i architektonicznych, a także innych działań przy zabytku wpisanym do rejestru zabytków oraz badań archeologicznych i poszukiwań ukrytych lub porzuconych zabytków ruchomych. Dz. U. z dnia 30 czerwca 2004 r. 
[4] Adamowski J., Hoła J., Matkowski Z. Probleme und Lösungen beim Feuchtigkeitsschutz des Mauerwerks von Baudenkmälern am Beispiel zweier grosser Barockbauten in Wroctaw. Bautechnik 82 (2006) 426-433.

[5] Rokiel M. Hydroizolacje w budownictwie. Grupa MEDIUM, Warszawa, 2006.

[6] CSN P 73 0610. Waterproofing of buildings - The rehabilitation of damp masonry and additional protection of buildings against ground moisture and against atmospheric water-The basic provision. 2000.

[7] Hoła A. Measuring of the moisture content in brick walls of historical buildings the overview of methods. 3rd International Conference on Innovative Materials, Structures and Technologies (IMST 2017) [Dokument elektroniczny]: 27-29 September 2017, Riga, Latvia. [Bristol]: IOP Publishing, 2017.

[8] WTA 2-6-99-D. Erganzungen zum WTA-Merkblatt 2-2-91-D. Sanierputzsysteme.

[9] Goetzke-Pala A., Hoła A., Sadowski Ł. A new method of the non-destructive evaluation of the moisture in saline brick walls using artificial neural networks. Construction \& Building Materials (w recenzji).

[10] Hoła J., Matkowski Z. Wybrane problemy dotyczace zabezpieczeń przeciwwilgociowych ścian w istniejacych obiektach murowanych. Awarie budowlane, XXIV Konferencja Naukowo-Techniczna, Szczecin-Międzyzdroje 2009, 73-92.

[11] Kubik J. Przeptyw wilgoci w materiałach budowlanych. Oficyna Wydawnicza Politechniki Opolskiej, Opole 2000.

[12] Raimondo M., Dondi M., Guardini G., Mazzanti F. Predicting the initial rate of water absorption in clay brick. Construction and Building Materials 23 (2009) 2623-2630.

[13] Alsabry A. Dynamika podciagania kapilarnego w murach budowlanych. Przegląd Budowlany 9 (2010) 46-48.

[14] Goetzke-Pala A. Identyfikacja wilgotności murów ceglanych na podstawie badań nieniszczacych $z$ wykorzystaniem sztucznych sieci neuronowych. Raport serii PRE nr 1/2016. Praca doktorska. Politechnika Wrocławska, Wrocław 2016.

[15] Espinosa R. M., Franke L., Deckelmann G. Phase changes of salts in porous materials. Crystallization, hydration and deliquescence. Construction and Building Materials 22 (2008) 1758-1773.

[16] Gentillini C., Franzoni E., Brandini S., Nobile L. Effect of salt crystallization on the shear behavior of masonry walls. An experimental study. Construction and Building Materials 37 (2012) 181-189.

[17] Wołoch F., Gaczek M., Fiszer S. Oddziaływanie soli na elementy budynku. Builder 12 (2017) 70-74.

[18] Frössel F. Osuszanie murów i renowacja piwnic. Wydawnictwo Polcen, Warszawa 2007.

[19] Płoński W. Problemy wilgoci w przegrodach budowlanych. Wydawnictwo Arkady, Warszawa 1968.

[20] Praca zbiorowa. Ochrona budynków przed korozją biologiczną. (ed. Ważny J., Karyś J.). Wydawnictwo Arkady, Warszawa 2001.

[21] Goetzke-Pala A. Badania wilgotności zasolonej cegły ceramicznej nieniszczaca metoda dielektryczna. Materiały Budowlane 6 (2013) 60-62.

[22] Goetzke-Pala A. Badania wilgotności zasolonych murów ceglanych metodą mikrofalową. Materiały Budowlane 9 (2016) 104-106.

[23] Goetzke-Pala A., Hoła J. Influence of burnt clay brick salinity on moisture content evaluated by non-destructive electric methods. Archives of Civil and Mechanical Engineering 16 (2016) $101-111$.

[24] Goetzke-Pala A., Hoła J., Sadowski K. Non-destructive neural identification of the moisture content of saline ceramic bricks. Construction and Building Materials 113 (2016) 144-152.

[25] Wójcik R. Hydrofobizacja i uszczelnianie przegród murowych metoda iniekcji termicznej. Monografia habilitacyjna. Uniwersytet Warmińsko-Mazurski. Olsztyn, 2006. 
[26] Adamowski J., Hoła J., Matkowski Z. Metody osuszania przegród budowlanych. Materiały Budowlane 1 (2007) 110-114.

[27] Karyś J. i in. Ochrona budynków przed wilgocia i korozją biologiczną. Wydawnictwo Arkady, Warszawa 2010.

[28] Terlikowski W. Diagnozowanie konstrukcji budynków zabytkowych [w:] Naprawy i wzmocnienia konstrukcji budowlanych. Tom III. XXX Jubileuszowe Ogólnopolskie Warsztaty Pracy Projektanta Konstrukcji. Szczyrk 2015.

[29] Adamowski J., Matkowski Z. Osuszanie i renowacja budynków zalanych wodą. Izolacje przeciwwilgociowe. [w:] Naprawy i wzmocnienia konstrukcji budowlanych. Tom I. XXX Jubileuszowe Ogólnopolskie Warsztaty Pracy Projektanta Konstrukcji. Szczyrk 2015.

[30] Wójcik R. Docieplanie budynków od wewnątrz. Grupa MEDIUM. Warszawa, 2017.

\title{
The degradation of historic buildings due to excessive moisture - selected issues
}

\author{
Jerzy Hoła \\ Zakład Budownictwa Ogólnego, Wydziat Budownictwa Ladowego i Wodnego, \\ Politechnika Wrocławska, e-mail: jerzy.hola@pwr.edu.pl
}

\begin{abstract}
The article presents selected, however, according to the author significant problems concerning the progressive degradation of historic buildings due to excessive moisture. The most important causes and effects of excessive moisture and salinity were highlighted. A decrease in the safety of a structure, a reduction of the thermal insulation of a building's partitions and the deterioration of the operating conditions in rooms were, among others, indicated as the effects. The conditions of testing moisture using nondestructive methods, indicating those methods that are useful in historic buildings, were described. Moreover, the possibility of using artificial neural networks for a reliable moisture assessment was indicated. Actions that should be taken to prevent the progressive degradation of historic buildings, which is caused by excessive moisture and salinity, were signalled in chronological order.
\end{abstract}

Keywords: historic buildings, degradation, excessive moisture, excessive salinity, moisture testing methods, artificial neural networks. 